\title{
Turkish University Students' Opinions towards Blood Donation
}

\author{
Sami Özgür ${ }^{1, *}$, Handan Ürek ${ }^{1}$, Kübra Kösal ${ }^{2}$ \\ ${ }^{1}$ Necatibey Education Faculty, Balikesir University, Turkey \\ ${ }^{2}$ Graduate School of Natural and Applied Sciences, Balıkesir University, Turkey
}

Copyright $\odot 2018$ by authors, all rights reserved. Authors agree that this article remains permanently open access under the terms of the Creative Commons Attribution License 4.0 International License

\begin{abstract}
University students constitute an important cohort for the supplement of voluntary blood donation considering their age and dynamism. With this study, it is aimed to find out Turkish university students' positive and negative opinions towards blood donation in addition to interpreting their motivators and barriers to this issue. For this reason, a qualitative study was conducted with a total of 141 students studying in one of the governmental universities in the west part of Turkey. Data were collected with the help of a semi-structured interview form which involved 10 questions and analyzed by means of content analysis. As a result, it was determined that university students possessed insufficient knowledge and misconceptions related to blood donation. Also, more than half of the students were found to not donate blood before. Being sensible was the most frequent reason stated by the students for donating blood. On the other hand, anemia was the main reason of not donating blood for females and fear was the main reason for males. In the light of the findings, it is thought that focusing on factors such as Red Crescent blood collection vehicle, blood collection stands at the university campuses and positive effects on health might play important role to turn university students into voluntary regular donors.
\end{abstract}

Keywords Blood Donation, University Students, Voluntariness

\section{Introduction}

Blood is the vital fluid which carries oxygen, nutrients, hormones, vitamins and antibodies to the tissues in the body and sends away the carbon dioxide and waste matters formed in the tissues from the body [1]. Blood consists of the plasma and cellular portion [2]. The plasma makes up nearly $55 \%$ of the blood. There are water, proteins and salts in addition to the nutrients, which are transported, in the plasma portion of the blood.
Through the World, every day it is required to keep available blood for people who get wounded due to traffic accidents, for thalassemia and hemophilia patients, for people who have been operated and for newborns that need fresh blood to change with the blood in their body. However, one of the most significant problems encountered in the health area in various countries and also in Turkey is the fact that blood and blood products cannot be reached sufficiently in the necessary situations [3]. Despite the advances in the medicine and technology in today's conditions, no alternative treatment could be discovered instead of the blood and its components [4].

Blood donation is one of our social and individual responsibilities [5]. The only source of blood is human and there is no alternative way for obtaining it except from human considering today's medical and technological conditions [6]. Kaya, Sezek and Doğan [3] indicate that blood donation ensures to raise awareness for fulfilling social responsibilities in addition to improving the values such as helping each other in the society by adding that each society has to conduct the necessary work and preparing in order to find the required blood. The conduction of that work and preparing in the national level is an obligation. In Turkey, the work related to the supplement of the blood and blood products that can be essential for the nation is conducted by Turkish Red Crescent.

Kınalı Bereketli [7] reports that Turkish Military Army has been the most important blood donation source in Turkey for long years. After the realization of the importance of civil blood donation, blood donation organization unit was founded in the content of Turkish Red Crescent Association in 1974 [8]. In 2005, a project called "Safe Blood Procurement Project" related to the conduction of blood services among Turkey was put into practice [8].

The first goal in safe blood procurement is the collection of blood from safe donors. World Health Organization addressed safe donor issue as the main theme in April, 2000 and highlighted safe donors as the first step of 
obtaining safe blood by using the catchword "Safe blood starts with me" [9].

It is pointed out that Turkey takes place in the bottom rows in terms of blood donation when compared to the developed countries [10]. While voluntary blood donation makes up $5 \%$ of the society population in the developed countries, this ratio is $1.5 \%$ in Turkey [10]. In addition, donations by repeat voluntary non-remunerated blood donors in Turkey were indicated to be fewer than $40 \%$ and this ratio is one of the lowest values among the countries in Europe [11]. On the other hand, blood donation has been reported to increase in the recent 10 years in Turkey [12]. Nevertheless, insufficiency in the number of voluntary blood donors still stands as an important problem for the country [4].

At this point, having correct knowledge related to blood donation carries vital importance. There are several researches related to people's knowledge, practice and attitudes towards blood donation conducted in various countries in the World. At this respect, undergraduate medical students' knowledge, attitudes and practices were investigated in Pakistani [13]. In addition, several studies were conducted with adults $[14,15]$ and university students [16] in the Kingdom of Saudi Arabia to investigate their knowledge, attitudes and motivations towards blood donation. Also, voluntary blood donation of physicians [17] and healthcare workers [18] was examined in Nigeria. Besides, Gazibara et al. [19] investigated the attitudes of medical students towards blood donation in terms of several variables in Serbia. Moreover, this issue was handled in India by Uma, Arun and Arumugam [20] and Dubey, Sonker, Chaurasia and Chaudhary [21]; in China by Zaller, Nelson, Ness, Wen, Bai and Shan [22]; in Iran by Mousavi et al. [23]; in Ethiopia by Melku et al. [24]; in various developing countries by Lownik, Riley, Konstenius, Riley and McCullough [25]; in Cameroon by Koster and Hassall [26]; in Greece by Kalargirou, Beloukas, Kosma, Nanou, Saridi and Kriebardis [27] and in the USA by Glynn et al. [28].

Despite the body of research conducted in the World, there are a limited number of studies related to that issue in Turkey. In their study, Yildiz et al. [10] researched the reasons of the population for not donating blood in a southern city of Turkey. In addition, Kaya, Sezek and Doğan [3] investigated the attitudes of Turkish university students towards blood donation and the effect of their field knowledge on blood donation. Hablemitoğlu, Özkan and Yildırım [4] conducted a research on teachers to find out their attitudes towards blood donation as an example of devotion. Besides, Çelik and Güven [5] aimed to develop a valid and reliable scale in order to measure the attitudes of university students towards blood donation in their study.

Cevizci, Erginöz and Yüceokur [29] stated that most developing countries experience difficulty in finding blood donors and the researchers explained the most significant reasons of this situation as low levels of voluntary blood donation as well as societies' incorrect knowledge, belief, attitude and behavior about this issue. In addition to the studies about the investigation of knowledge, attitude and behavior of the individuals on blood donation as mentioned above, factors which trigger people for blood donation carry importance. In the literature, there are several researches focusing on the factors that motivate donors.

France, France, Wissel, Kowalsky, Bolinger and Huckins [30] investigated the effect of coping materials in written and audiovisual formats on willingness of donors at this respect in the USA. Also, Merav and Lena [31] explored the effect of Theory of Planned Behavior on the prediction of intention and actual blood donation among Israeli adults. Additionally, Veldhuizen, Ferguson, de Kort, Donders and Atsma [32] investigated the effect of blood donation experience considering the theory of planned behavior on blood donation in the Netherlands. In another study, van Dongen, Abraham, Ruiter and Veldhuizen [33] explored the effect of questionnaires on people's blood donation in the Netherlands. Guiddi, Alfieri, Marta and Saturni [34] investigated the motivation of Italian donors in terms of new donors, regular donors and loyal donors. Also, France et al. [35] explored the effect of motivational interviews with action and coping planning on blood donors' motivation in the USA. What is more, Alfieri, Guiddi, Marta and Saturni [36] handled this issue by considering the effect of economic crisis on Italian donors' motivation.

On the other hand, few studies considered this issue from the opposite and focused on the barriers to blood donation. At this respect, Shaz et al. [37] explored the barriers to blood donation of African American college students in the USA in addition to the motivators. Also, Pentecorst, Arli and Thiele [38] investigated the barriers to blood donation in Australia.

As can be seen in the literature, different aspects affecting blood donation were addressed in the studies. When a comparison is made, it is clear that there are more studies related to the approaches of the individuals towards blood donation. However; there are fewer studies related to the motivators at this respect. Especially, it is realized that few studies considered the barriers to blood donation.

According to Kaya, Sezek and Doğan [3], the significance of blood donation should be explained with various methods; voluntary blood donation should be encouraged; potential blood donors should be educated to avoid incorrect knowledge and belief and effective support should be requested from media about blood donation in order to raise the ratio of blood donation. Since it is thought that conducted body of research in Turkey is not sufficient, the deficiencies are tried to be addressed in the present study.

As mentioned earlier, the most important blood donation source of Turkey has been declared as Turkish Military Army. However it is seen that this source is not adequate considering the growing aspect of the country's population. 
It is thought that university level students can supply an important amount of blood need since those students are more dynamic in terms of their age group and they are more aware about blood donation. Therefore it is required to learn their positive and negative opinions about blood donation. Thus, it is foreseen that the studies which will be conducted in the light of the determined data in this research will be more practicable.

The focus of the present study is the fact that university level students who are one of the civil sources of blood donation are seen as an important element of blood donor pool. With this study, it is aimed to comprehend the feelings and opinions of those individuals while donating blood. Thus, it will be possible to utilize collected data in terms of awareness studies at this respect. Besides, finding out the knowledge level of the students about blood donation, investigating their incorrect knowledge and belief about blood donation and showing up their positive and negative opinions related to blood donation can be regarded among the aims of the study. So, it will be possible to investigate the opinions, practice and behavior of university students towards blood donation in addition to interpreting their motivators and barriers to this issue. Also, it is expected to contribute to the gap in the literature with the present study.

\section{Methods}

The present study is a qualitative study which was conducted in order to investigate the opinions of the students studying at a governmental university located at the west part of Turkey about blood donation with the help of a semi-structured interview form [39]. Qualitative methods were embraced in terms of the selection of study sample, development of data collection instrument and data analysis.

\subsection{The Study Sample}

The study sample consisted of a total of 141 university students studying at a governmental university located at the west part of Turkey. The study sample was formed via convenience sampling from purposeful sampling methods. This approach makes the researchers gain quickness and practicality towards the study targets [39]. The focus of this study was on university students who were accessed easily by the researchers depending on voluntariness from the canteens, gardens and libraries of several faculties of the considered university.

From the participants, 66 (46.8\%) of them were females whereas $75(53.2 \%)$ of them were males. Table 1 displays the details related to the distribution of the participants' age.
Table 1. Distribution of the age of the study sample

\begin{tabular}{|c|c|}
\hline Age & \% (f) \\
\hline 18 & $5.67 \%(8)$ \\
\hline 19 & $11.35 \%(16)$ \\
\hline 20 & $20.57 \%(29)$ \\
\hline 21 & $18.44 \%(26)$ \\
\hline 22 & $13.48 \%(19)$ \\
\hline 23 and above & $30.49 \%(43)$ \\
\hline Total & $100.00 \%(141)$ \\
\hline
\end{tabular}

As can be seen on Table 1, the group with the highest frequency in the participants belonged to the age 23 and above $(30.49 \%, f=43)$. On the other hand, the group with the least frequency belonged to the age $18(5.67 \%, \mathrm{f}=8)$.

\subsection{Data Collection and Analysis}

A semi-structured interview form was utilized as data collection instrument in the study. Before data collection process, the participants were informed about the aims of the study and expected contributions to it. The interview form involved 10 questions. Each interview elapsed about 20 minutes. The questions were asked one by one by the researchers to get answers from the participants. The interviews were recorded with a voice-recorder. Then collected data were transcribed. The study was an anonym study since the names of the participants were not asked.

The study involved two stages. The first stage was the pilot study whereas the second stage was the real study. In the first stage, the interview form which involved 8 questions was applied to 15 university students. According to data obtained from this study, it was realized that the students answered more than 8 questions in practice. Hence the questions were restructured and the number of the questions was increased according their answers. The number of the questions in the interview form was determined to be 10 .

The opinions of two experts were taken related to the questions in the pilot study. At this respect, each question's adequacy for measuring university level students' feelings, opinions and knowledge related to blood donation was asked as well as the questions' format related to item writing techniques. Also, the interview form was checked in terms of its level, content, context and language by the field experts. The form was improved in terms of the intelligibility and clearance of several items considering its language in the light of the opinions of the experts and a final state was given to it.

The questions in the form which resulted in quantitative and qualitative data can be explained by the following:

- Collection of quantitative data: gender, age, blood donation period, blood donation time

- Collection of qualitative data: donation status, reasons, drawbacks, blood donors, who to donate, which arm to donate, blood donation triggers 
Data obtained from the study were analyzed and interpreted with the help of content analysis which is a frequently utilized method in qualitative studies [39]. Before the analysis, the categories were determined by the researchers considering the target of the study. The themes and sub-themes found out in the study were arranged under those categories. An analysis table was prepared for each question. The analyses of the findings were presented to make comparisons with respect to the gender of the students.

\section{Findings}

The findings obtained from the analyses of the interviews are presented as the order of the questions in the semi-structured interview form.

\subsection{Findings Obtained from the Analysis of Question 1: Do You Know Your Blood Group?}

The findings obtained from the analysis of Question 1 which indicated students' awareness about their blood group was shown on Table 2.

Table 2. Distribution of the participants' awareness of their blood group

\begin{tabular}{|c|c|c|}
\hline Themes & Female \% (f) & Male \% (f) \\
\hline Yes & $81.82 \%(54)$ & $74.67 \%(56)$ \\
\hline No & $18.18 \%(12)$ & $25.33 \%(19)$ \\
\hline Total & $100.00 \%(66)$ & $100.00 \%(75)$ \\
\hline
\end{tabular}

According to Table 2, $18.18 \%$ (12) of the female students responded to the question "Do you know your blood group?" as no whereas $25.33 \%$ (19) of the male students responded to this question as no. In other words, each of one male from every four male students did not know their blood group. Additionally, when a comparison was made, there was not much difference between male and female students in terms of knowing their blood groups However the frequency of the students who did not know their blood groups was found to be high when the participants were considered to be university level students.

\subsection{Findings Obtained from the Analysis of Question 2: Have You Ever Donated Blood Before? (If Your Answer Is Yes, How Many Times?) Please Explain Your Reason.}

The findings obtained from the analysis of Question 2 related to the status of donation of blood before were shown on Table 3. In addition, blood donation time was presented as sub-themes for those who donated blood before under the theme, yes I have.
Table 3. Blood donation status

\begin{tabular}{|c|c|c|c|}
\hline \multicolumn{1}{|c|}{ Themes } & Female \% (f) & Male \% (f) \\
\hline \multicolumn{2}{|c|}{ No, I have not } & $60.61 \%(40)$ & $49.33 \%(37)$ \\
\hline \multicolumn{2}{|c|}{ Yes, I have } & $39.39 \%(26)$ & $50.67 \%(38)$ \\
\cline { 2 - 4 } $\begin{array}{c}\text { Sub-Them } \\
\text { es }\end{array}$ & Once & $7.57 \%(5)$ & $14.67 \%(11)$ \\
\cline { 2 - 4 } & Twice & $13.64 \%(9)$ & $6.66 \%(5)$ \\
\cline { 2 - 4 } & Four times & $7.57 \%(5)$ & $6.66 \%(5)$ \\
\cline { 2 - 4 } & $\begin{array}{c}\text { Five times and } \\
\text { more }\end{array}$ & $4.55 \%(3)$ & $16.00 \%(12)$ \\
\hline \multicolumn{2}{|c|}{ Total } & $100.00 \%(66)$ & $100.00 \%(75)$ \\
\hline
\end{tabular}

As demonstrated on Table 3, 60.61\% (40) of the female students and $49.33 \%$ (37) of the male students had never donated blood before. In other words, more than half of the female students had never donated blood before. When the case of male students were considered, it was seen that about half of them $(49.33 \%, f=37)$ had never donated blood before.

The data obtained from the analysis of this question are very important because they indicate evidence for us to understand the reasons of university students related to blood donation. The reasons of both positive and negative answers were examined at this respect.

\subsubsection{Findings Related to the Reasons of Negative Answers}

Table 4 showed the findings related to the reasons of the students who had not donated blood before. Their reasons were organized in the form of themes and sub-themes.

Table 4. Reasons for being not donated blood before

\begin{tabular}{|c|c|c|c|}
\hline Themes & Sub-Themes & Female \% (f) & Male \% (f) \\
\hline \multirow{3}{*}{ Health } & $\begin{array}{c}\text { Anemia (low blood } \\
\text { variable) }\end{array}$ & $42.50 \%(17)$ & $13.51 \%(5)$ \\
\cline { 2 - 4 } & Weight & $7.50 \%(3)$ & $5.41 \%(2)$ \\
\cline { 2 - 4 } & Infectious disease & $2.50 \%(1)$ & $10.81 \%(4)$ \\
\cline { 2 - 4 } & Age & $2.50 \%(1)$ & $2.70 \%(1)$ \\
\hline \multirow{3}{*}{ Other } & I am afraid & $15.00 \%(6)$ & $29.73 \%(11)$ \\
\cline { 2 - 4 } & No occasion & $15.00 \%(6)$ & $10.81 \%(4)$ \\
\cline { 2 - 4 } & Mistrust & - & $5.41 \%(2)$ \\
\cline { 2 - 4 } & Other & $15.00 \%(6)$ & $21.62 \%(8)$ \\
\hline & Total & $100.00 \%(40)$ & $100.00 \%(37)$ \\
\hline
\end{tabular}

According to Table 4, the reasons of the female students for not donating blood before were determined as anemia $(42.50 \%, \mathrm{f}=17)$; weight $(7.50 \%, \mathrm{f}=3)$; infectious disease $(2.50 \%, \mathrm{f}=1)$ and age $(2.50 \%, \mathrm{f}=1)$. As a result, $55.00 \%(22)$ of the female participants stated that they had never donated blood before due to valid reasons. On the other hand, the reasons of male students for not donating blood were determined as anemia $(13.51 \%, \mathrm{f}=5)$; weight $(5.41 \%, \mathrm{f}=2)$; infectious disease $(10.81 \%, \mathrm{f}=4)$ and age $(2.70 \%, \mathrm{f}=1)$. So $32.43 \%$ (12) of the male students pointed 
out that they had never donated blood before due to their valid reasons. However, $45.00 \%$ (18) of the female students and $67.57 \%$ (25) of the male students proposed other reasons for not donating blood such as "I am afraid", "no occasion" and "I do not trust". This part is especially an important point for the researchers in practice. Male and female university students who do not donate blood without a valid reason in the sample $(30.50 \%, \mathrm{f}=43)$ can be convinced to be a regular blood donor whether adequate conditions are supplied for them.

\subsubsection{Findings Related to the Reasons of Positive Answers}

Table 5 showed the findings related to the reasons of the students who had donated blood before. Their reasons were organized in the form of themes and sub-themes also.

Table 5. Reasons for being donated blood before

\begin{tabular}{|c|c|c|c|}
\hline Themes & Sub-Themes & Female \% (f) & Male \% (f) \\
\hline \multirow{3}{*}{ Life } & Being sensible & $38.46 \%(10)$ & $50.00 \%(19)$ \\
\hline & For health & $23.08 \%(6)$ & $13.16 \%(5)$ \\
\hline & Happiness & $3.85 \%(1)$ & $2.63 \%(1)$ \\
\hline \multirow{2}{*}{ Other } & When coincided & $23.08 \%(6)$ & $13.16 \%(5)$ \\
\hline & Regularly & $11.54 \%(3)$ & $21.05 \%(8)$ \\
\hline \multicolumn{2}{|r|}{ Total } & $100.00 \%(26)$ & $100.00 \%$ \\
\hline
\end{tabular}

On Table 5, from the students who stated "yes" to the question "Have you ever donate blood before?", it was seen that $38.46 \%(\mathrm{f}=10)$ of the female students and $50.00 \%$ $(\mathrm{f}=19)$ of the male students pointed out that they had donated blood because they cared about people and they felt peace. In addition, one of every four female students and $13.16 \%(f=5)$ of the male students said that they had donated blood for their health. Also, it was seen that there was a total of 11 students $(7.80 \%)$ who explained that they had donated blood when they coincided with Red Crescent Blood Collection Vehicle.

It is seen that the motivation factors of university students for blood donation can be gathered under three main themes:
i. Due to feeling themselves useful for the society
ii. Blood donation gives health to the donor
iii. Red Crescent Blood Collection Vehicle is a trigger for blood donation itself

It is required for the related foundations to consider the abovementioned aspects unconditionally in order to be accomplished in the studies to arouse awareness about blood donation.

\subsection{Findings Obtained from the Analysis of Question 3: In What Periods Do You Donate Blood? Please Explain Your Reason.}

Table 6 indicated the time for period of the participants' blood donation (Those participants could also be seen among the answers "yes" on Table 3).
Table 6. Period of blood donation

\begin{tabular}{|c|c|c|}
\hline Period & Female \% (f) & Male \% (f) \\
\hline 3 Months & - & $4.00 \%(3)$ \\
\hline 6 Months & $19.69 \%(13)$ & $20.00 \%(15)$ \\
\hline 1 Year & $12.12 \%(8)$ & $10.67 \%(8)$ \\
\hline 2 Years and more & $7.58 \%(5)$ & $16.00 \%(12)$ \\
\hline Total & $39.39 \%(26)$ & $50.67 \%(38)$ \\
\hline
\end{tabular}

According to Table 6, blood donating female students explained that they donated blood in 6 months periods $(19.69 \%, \mathrm{f}=13)$; once a year $(12.12 \%, \mathrm{f}=8)$; in two years and more periods $(7.58 \%, \mathrm{f}=5)$. On the other hand blood donating male students stated that they donated blood in 3 months periods $(4.00 \%, \mathrm{f}=3)$; in 6 months periods $(20.00 \%$, $\mathrm{f}=15)$; once a year $(10.67 \%, \mathrm{f}=8)$ and in two years and more periods $(16.00 \%, \mathrm{f}=12)$.

Only $22.00 \%$ (31) of blood donating university students expressed that they donated blood in every 3 or 6 months. It is thought that especially the subject of "being a regular donor" should be addressed in the awareness studies at this respect.

\subsection{Findings Obtained from the Analysis of Question 4: What Is Your Most Important Reason for Donating/Not Donating Blood?}

Table 7 indicated the most important reasons of the students related to donating or not donating blood. The findings were organized as the positive (I donate) and negative answers (I do not donate) under the main themes in addition to explaining their details under sub-themes.

Table 7. Reasons for donating/not donating blood

\begin{tabular}{|c|c|c|c|}
\hline Themes & Sub-Themes & Female \% (f) & Male \% (f) \\
\hline \multirow{5}{*}{ I donate } & Being sensible & $24.24 \%(16)$ & $\begin{array}{l}21.33 \% \\
(16)\end{array}$ \\
\hline & Good for health & $13.64 \%(9)$ & $\begin{array}{c}16.00 \% \\
(12)\end{array}$ \\
\hline & Happiness & $3.03 \%(2)$ & $6.67 \%(5)$ \\
\hline & Empathy & $3.03 \%(2)$ & $5.33 \%(4)$ \\
\hline & $\begin{array}{l}\text { My blood group is not } \\
\text { frequent }\end{array}$ & - & $1.33 \%(1)$ \\
\hline \multirow{8}{*}{$\begin{array}{l}\text { I do not } \\
\text { donate }\end{array}$} & $\begin{array}{c}\text { Anemia or I may be } \\
\text { anemia }\end{array}$ & $24.24 \%(16)$ & $4.00 \%(3)$ \\
\hline & I am afraid & $9.09 \%(6)$ & $\begin{array}{c}18.67 \% \\
(14)\end{array}$ \\
\hline & Not coincided & $7.58 \%(5)$ & $8.00 \%(6)$ \\
\hline & Weight & $6.06 \%(4)$ & $2.67 \%(2)$ \\
\hline & I take medicine & $3.03 \%(2)$ & $6.67 \%(5)$ \\
\hline & $\begin{array}{l}\text { I do not know my } \\
\text { blood group }\end{array}$ & $3.03 \%(2)$ & $1.33 \%(1)$ \\
\hline & I do not trust & $1.51 \%(1)$ & $6.67 \%(5)$ \\
\hline & Age & $1.51 \%(1)$ & $1.33 \%(1)$ \\
\hline \multicolumn{2}{|r|}{ Total } & $100.00 \%(66)$ & $\begin{array}{c}100.00 \% \\
(75)\end{array}$ \\
\hline
\end{tabular}

Table 7 indicated that students' responses were similar to 
their responses in the $2^{\text {nd }}$ question (Have you ever donate blood before? (If your answer is yes, how many times? Please explain your reason). The reason of female students with the highest percentage (24.24\%) and frequency ( $\mathrm{f}=16)$ was found as the fact that "I am anemia" or "I may be anemia". On the other hand, the reason of the male students with the highest percentage $(18.67 \%)$ and frequency ( $\mathrm{f}=14)$ was found as the fact that "I am afraid" for this issue.

When Table 7 was examined, it was seen that the reasons such as "I do not trust", "I do not know my blood group", "I may be anemia" and "I am afraid" constitute $34.04 \%$ ( $\mathrm{f}=48$ ) of the reasons. Those reasons indicated that the students did not possess sufficient knowledge about blood and blood donation. It is thought that this issue should seriously be considered in the campaigns to trigger blood donation.

\subsection{Findings Obtained from the Analysis of Question 5: From Which Arm Can Blood Be Donated? Please Explain Your Reason}

The participants' opinions related to the arm to donate blood are presented on Table 8 by providing details about their explanations under sub-themes.

Table 8. Description of the arm to donate blood

\begin{tabular}{|c|c|c|c|}
\hline Themes & Sub-Themes & Female \% (f) & Male \% (f) \\
\hline \multirow{4}{*}{ Left } & Closeness to the hearth & $9.09 \%(6)$ & $5.33 \%(4)$ \\
\cline { 2 - 4 } & Clean blood & $6.06 \%(4)$ & $1.33 \%(1)$ \\
\cline { 2 - 4 } & Observations & $4.55 \%(3)$ & $5.33 \%(4)$ \\
\cline { 2 - 4 } & $\begin{array}{c}\text { Carotid artery and heart } \\
\text { is on the left }\end{array}$ & - & $4.00 \%(3)$ \\
\cline { 2 - 4 } & Clarity of vessel & - & $1.33 \%(1)$ \\
\hline \multirow{3}{*}{ Right } & Clean blood & $6.06 \%(4)$ & $6.67 \%(5)$ \\
\cline { 2 - 4 } & Observations & $1.51 \%(1)$ & $8.00 \%(6)$ \\
\hline \multirow{4}{*}{$\begin{array}{c}\text { Both } \\
\text { Arms }\end{array}$} & Correct explanations & $43.94 \%(29)$ & $\begin{array}{c}32.00 \% \\
(24)\end{array}$ \\
\cline { 2 - 4 } & I do not know & $15.15 \%(10)$ & $\begin{array}{c}13.33 \% \\
(10)\end{array}$ \\
\cline { 2 - 4 } & Predictions & $4.55 \%(3)$ & $5.33 \%(4)$ \\
\cline { 2 - 4 } & Meaningless & $3.03 \%(2)$ & $8.00 \%(6)$ \\
\cline { 2 - 4 } & Observations & $3.03 \%(2)$ & $8.00 \%(6)$ \\
\hline \multirow{4}{*}{} & No response & $3.03 \%(2)$ & $1.33 \%(1)$ \\
\hline \multirow{2}{*}{} & Total & $100.00 \%(66)$ & $\begin{array}{c}100.00 \% \\
(75)\end{array}$ \\
\hline
\end{tabular}

When Table 8 was examined, it was determined that the findings obtained from the analysis of that question were related to the misconceptions about biology education, not related to blood donation. $6.06 \%(\mathrm{f}=4)$ of the females stated that blood donation was made from the left arm since clean blood circled in the left side of the body. Also, 5.33\% ( $\mathrm{f}=4)$ of the males explained that blood donation was made from the left arm since it was closer to the hearth. On the other hand, $43.94 \%$ ( $\mathrm{f}=29$ ) of the female students made correct explanations by asserting that blood donation could be made from both arms. Additionally, it was determined that
$32.00 \%(\mathrm{f}=24)$ of the male students gave the correct answer.

\subsection{Findings Obtained from the Analysis of Question 6: Is It Good for Health to Donate Blood?}

Table 9 demonstrated whether the students thought blood donation was good for their health or not.

Table 9. Is blood donation good for health?

\begin{tabular}{|c|c|c|}
\hline Themes & Female \% (f) & Male \% (f) \\
\hline Yes & $93.94 \%(62)$ & $84.00 \%(63)$ \\
\hline No & - & $5.33 \%(4)$ \\
\hline I do not know & $6.06 \%(4)$ & $10.67 \%(8)$ \\
\hline Total & $100.00 \%(66)$ & $100.00 \%(75)$ \\
\hline
\end{tabular}

According to Table 9, 6.06\% ( $\mathrm{f}=4)$ of the female students and $16.00 \%(\mathrm{f}=12)$ of the male students did not know whether blood donation was beneficial for their health. Those university students can be convinced to make blood donation via awareness studies or boost. Thus, attendance of those students to blood donation can be accomplished.

\subsection{Findings Obtained from the Analysis of Question 7: Is There Any Drawbacks of Blood Donation?}

Table 10 introduced students' opinions whether there were drawbacks of blood donation. Also, their concerns related to blood donation were examined under sub-themes on Table 10.

Table 10. Opinions related to the drawbacks of blood donation

\begin{tabular}{|c|c|c|c|}
\hline Themes & Sub-Themes & Female \% (f) & Male \% (f) \\
\hline \multirow{4}{*}{$\begin{array}{c}\text { Yes, there are } \\
\text { drawbacks }\end{array}$} & $\begin{array}{c}\text { It makes anemia. } \\
\text { lassitude and } \\
\text { nausea. }\end{array}$ & $6.06 \%(4)$ & $2.67 \%(2)$ \\
\cline { 2 - 4 } & $\begin{array}{c}\text { It makes } \\
\text { hypotension and }\end{array}$ & $1.51 \%(1)$ & $8.00 \%(6)$ \\
\cline { 2 - 4 } & $\begin{array}{c}\text { It makes lassitude } \\
\text { and weight loss. }\end{array}$ & $16.67 \%(11)$ & $2.67 \%(2)$ \\
\cline { 2 - 5 } & It makes fainting. & $4.55 \%(3)$ & - \\
\cline { 2 - 4 } & $\begin{array}{c}\text { It may cause } \\
\text { infectious diseases } \\
\text { via blood. }\end{array}$ & $16.67 \%(11)$ & $30.67 \%(23)$ \\
\hline \multicolumn{2}{|c|}{ No, there are not drawbacks } & $45.45 \%(30)$ & $41.33 \%(31)$ \\
\hline \multicolumn{2}{|c|}{ I do not know } & $100.00 \%(66)$ & $100.00 \%(75)$ \\
\hline
\end{tabular}

On Table 10, it was seen that university students knew that there were no drawbacks of blood donation of healthy individuals. On the other hand, the opinion that blood donation might cause several diseases was frequent among university students. For example, $37.88 \%(\mathrm{f}=25)$ of the female students and $13.33 \%(\mathrm{f}=10)$ of the male students 
pointed out that blood donation had drawbacks such as hypoglycemia, anemia, lassitude and weight loss. Still, $16.67 \%(\mathrm{f}=11)$ of the female students and $30.67 \%(\mathrm{f}=23)$ of the male students thought that another drawback of blood donation might cause infectious diseases. The anxieties of the students should absolutely be considered by the institutions for the awareness studies to be conducted and for the education programs related to blood donation.

\subsection{Findings Obtained from the Analysis of Question 8: Who Can/Cannot Donate Blood?}

Students' opinions related to being and not being a blood donor were shown on Table 11 by providing their reasons under sub-themes.

Table 11. Opinions related to people who can/not donate blood

\begin{tabular}{|c|c|c|c|}
\hline Themes & Sub-Themes & Female \% (f) & Male \% (f) \\
\hline \multirow{2}{*}{$\begin{array}{c}\text { Can } \\
\text { donate }\end{array}$} & Healthy people & $35.71 \%(35)$ & $46.94 \%(46)$ \\
\hline & Everybody & $14.29 \%(14)$ & $13.27 \%(13)$ \\
\hline \multirow{10}{*}{$\begin{array}{l}\text { Cannot } \\
\text { donate }\end{array}$} & Gays & $3.06 \%(3)$ & $1.02 \%(1)$ \\
\hline & $\begin{array}{l}\text { People with tattoos or } \\
\text { piercings }\end{array}$ & $5.10 \%(5)$ & $3.06 \%(3)$ \\
\hline & $\begin{array}{c}\text { People with blood } \\
\text { deficiency }\end{array}$ & $2.04 \%(2)$ & - \\
\hline & Patients & $19.39 \%(19)$ & $18.37 \%(18)$ \\
\hline & $\begin{array}{c}\text { People with } \\
\text { overweight or } \\
\text { insufficient weight }\end{array}$ & $4.08 \%(4)$ & $2.04 \%(2)$ \\
\hline & People taking medicine & $3.06 \%(3)$ & - \\
\hline & $\begin{array}{l}\text { People with iron } \\
\text { deficiency }\end{array}$ & $1.02 \%(1)$ & - \\
\hline & $\begin{array}{c}\text { People whose age is } \\
\text { not convenient }\end{array}$ & $5.10 \%(5)$ & $7.14 \%(7)$ \\
\hline & Addicted people & $4.08 \%(4)$ & $5.10 \%(5)$ \\
\hline & Pregnant people & $2.04 \%(2)$ & $2.04 \%(2)$ \\
\hline \multicolumn{2}{|r|}{ I do not know } & $1.02 \%(1)$ & $1.02 \%(1)$ \\
\hline \multicolumn{2}{|r|}{ Total } & $100.00 \%(98)$ & $100.00 \%(98)$ \\
\hline
\end{tabular}

According to Table 11, it was clear that the students provided more than one answer to the $8^{\text {th }}$ question as can be understood from the frequencies. From the participants, $35.71 \%$ ( $f=35$ ) of the females and $46.94 \%(f=46)$ of males pointed out that healthy people could donate blood. $19.39 \%$ $(\mathrm{f}=19)$ of females and $18.37 \%$ ( $\mathrm{f}=18)$ of males explained that patients could not donate blood. In here, female and male students thought that being healthy was satisfactory to donate blood but they pointed out that people with unhealthy conditions such as abnormal weight, addiction could not donate blood.

It is seen that two results arise according to the answers provided by the students to that question:

- Nearly most of the students gave correct answers to the question.

- Despite the fact that the students provided correct answers to the question, why did they $(60.61 \%$
[ $\mathrm{f}=40]$ of the females and $49.33 \%$ [ $\mathrm{f}=37]$ of the males) declare that they had never donated blood before?

\subsection{Findings Obtained from the Analysis of Question 9: Do/Don't You Donate Blood When a Relative of You Needs? Please Explain Your Reason}

Table 12 presented students' opinions about donating blood when their relatives needed it with their reasons.

Table 12. Opinions about donating/not donating blood to a relative

\begin{tabular}{|c|c|c|c|}
\hline Themes & Sub-Themes & $\begin{array}{c}\text { Female } \\
\% \text { (f) }\end{array}$ & $\begin{array}{l}\text { Male } \\
\% \text { (f) }\end{array}$ \\
\hline \multirow{3}{*}{ I donate } & Since $\mathrm{s} / \mathrm{he}$ is a closer. & $\begin{array}{c}34.85 \% \\
(23) \\
\end{array}$ & $\begin{array}{c}37.33 \% \\
(28) \\
\end{array}$ \\
\hline & Blood is a need. & $\begin{array}{l}10.61 \% \\
(7)\end{array}$ & $9.33 \%(7)$ \\
\hline & Sensibility & $\begin{array}{c}34.85 \% \\
(23)\end{array}$ & $\begin{array}{c}40.00 \% \\
(30)\end{array}$ \\
\hline \multirow{6}{*}{$\begin{array}{l}\text { I do not } \\
\text { donate }\end{array}$} & $\begin{array}{l}\text { Blood exchange in the } \\
\text { family has drawbacks. }\end{array}$ & $1.51 \%(1)$ & - \\
\hline & I have low blood variables. & $\begin{array}{c}10.61 \% \\
(7) \\
\end{array}$ & $2.67 \%(2)$ \\
\hline & My blood is valuable. & $1.51 \%(1)$ & - \\
\hline & I do not know. & $1.51 \%(1)$ & $1.33 \%(1)$ \\
\hline & I am afraid (hemophobia). & $3.03 \%(2)$ & $8.00 \%(6)$ \\
\hline & Unsterile conditions & $1.51 \%(1)$ & $1.33 \%(1)$ \\
\hline & Total & $\begin{array}{l}100.00 \% \\
(66)\end{array}$ & $\begin{array}{c}100.00 \% \\
(75)\end{array}$ \\
\hline
\end{tabular}

When Table 12 was considered, it was seen that $34.85 \%$ $(\mathrm{f}=23)$ of the female students and $37.33 \%(\mathrm{f}=28)$ of the male students replied that they could donate blood when their relatives needed. Besides, $34.85 \%(f=23)$ of the females and $40.00 \%$ ( $f=30$ ) of the males explained that they could donate blood to their relatives due to their sensibility. On the other hand, misconceptions were identified among several students who indicated that they could not donate blood even to their relatives. For example, one of such response stated by a female student $(1.51 \%)$ was as follows: "Blood exchange in the family has drawbacks.". The students who stated that they could not donate blood due to the fact that their blood variables were low had $10.61 \%(\mathrm{f}=7)$ among female students and $2.67 \%$ $(\mathrm{f}=2)$ among male students. Giving place to the fact that such fears are unjustifiable in the awareness studies might trigger those students to donate blood.

\subsection{Findings Obtained from the Analysis of Question 10: Do you feel to Donate Blood When You See Red Crescent Institutions and Blood Vehicles in the Social Media or in the Environment around You? Please List Your Reasons.}

Table 13 demonstrated students' opinions related to Red Crescent in terms of triggering blood donation with their reasons. 
Table 13. Opinions about Red Crescent triggering blood donation

\begin{tabular}{|c|c|c|c|c|}
\hline Themes & \multicolumn{2}{|r|}{ Sub-Themes } & Female \% (f) & Male \% (f) \\
\hline \multirow{14}{*}{ I feel } & \multirow{7}{*}{ I donate } & To help & $40.91 \%(27)$ & $28.00 \%(21)$ \\
\hline & & Red Crescent blood vehicle triggers & $12.12 \%(8)$ & $8.00 \%(6)$ \\
\hline & & No reason & $7.58 \%(5)$ & $9.33 \%(7)$ \\
\hline & & It is healthy. & $3.03 \%(2)$ & - \\
\hline & & To donate blood regularly & - & $4.00 \%(3)$ \\
\hline & & Engrossing & - & $4.00 \%(3)$ \\
\hline & & Awareness & - & $1.33 \%(1)$ \\
\hline & \multirow{7}{*}{$\begin{array}{l}\text { I do but I cannot } \\
\text { donate }\end{array}$} & I am patient. & $1.51 \%(1)$ & $2.67 \%(2)$ \\
\hline & & I have anemia. & $10.61 \%(7)$ & $4.00 \%(3)$ \\
\hline & & I am afraid (hemophobia). & $4.55 \%(3)$ & $4.00 \%(3)$ \\
\hline & & I do not know my blood group. & $1.51 \%(1)$ & - \\
\hline & & I have no time. & - & $1.33 \%(1)$ \\
\hline & & I am unwilling. & - & $1.33 \%(1)$ \\
\hline & & There is no sufficient hygiene. & - & $1.33 \%(1)$ \\
\hline \multirow{7}{*}{\multicolumn{2}{|c|}{ I do not feel }} & Blood Collection Vehicle did not come up. & $3.03 \%(2)$ & $5.33 \%(4)$ \\
\hline & & The stuff is not nice and persistent. & $1.51 \%(1)$ & $2.67 \%(2)$ \\
\hline & & Hemophobia & $6.06 \%(4)$ & - \\
\hline & & $\begin{array}{l}\text { Not believing and/or trusting that collected blood reaches } \\
\text { people who need it. }\end{array}$ & $6.06 \%(4)$ & $17.33 \%(13)$ \\
\hline & & I have anemia. & $1.51 \%(1)$ & $1.33 \%(1)$ \\
\hline & & I have weight loss. & - & $1.33 \%(1)$ \\
\hline & & They sell it for money. & - & $2.67 \%(2)$ \\
\hline \multicolumn{3}{|r|}{ Total } & $100.00 \%(66)$ & $100.00 \%(75)$ \\
\hline
\end{tabular}

According to Table 13, 12.12\% $(\mathrm{f}=8)$ of the female students were found to think that observing Red Crescent Institutions and blood vehicle around them or in social media platforms was triggering for blood donation. Besides, $8.00 \%(f=6)$ of the male students found that situation triggering for blood donation also. Due to those answers, it can be proposed that social media platforms and Red Crescent Blood Collection Vehicles located in the universities should conduct more frequent activities in order to increase students' blood donation. 40.91\% ( $\mathrm{f}=27)$ of the females and similarly $28.00 \%$ ( $f=21$ ) of the males explained that they had the opinion to help as a reason of feeling to donate blood in that situation. By moving from that important finding, the institutions which conduct awareness studies related to this situation should give place to the activities which will address the feeling of empathy of university students. Also, 3.03\% $(\mathrm{f}=2)$ of the females and $5.33 \%(\mathrm{f}=4)$ of the males complained about the fact that the blood collection vehicle did not come up to them. In addition, it was seen that $6.06 \%(f=4)$ of the female students and $17.33 \%(\mathrm{f}=13)$ of the male students stated that they did not believe/trust as a reason of not feeling to donate blood. Moreover, $2.67 \%(\mathrm{f}=2)$ of the males students thought that collected blood was not given to the people who needed it and it was sold to the rich people for money.
Those significant opinions possessed by the students should absolutely be considered by the responsible people in blood collection institutions and convenient policies should be produced at this respect. At least, information related to the use of donated blood should be given to the donor via short message service or e-mail.

\section{Discussion}

In the present study related to the investigation of the opinions of university students on blood donation, it was seen that more than half of the university students had never donated blood yet. At this point, two questions which also constituted the main focus of the present study emerged:

- Firstly, with which reasons did the students who donated blood conduct their behavior?

- Secondly, what were the reasons of the students who had never donated blood before?

The findings of the study will be discussed in terms of those questions. Firstly, possible reasons which influence blood donation negatively will be addressed in the following part:

It was seen that nearly one out of five female students 
and one out of four male students did not know their blood group. The total number of the participants who knew their blood group in the present study was a little better than the findings of a previous study conducted with Turkish adults [10]. This result is promising when the sample is considered to consist of university students. It is thought that one way of developing positive attitudes towards blood donation passes from the recognition of the characteristics and importance of blood and blood products. Unfortunately, the literature has been full of studies showing people who lack sufficient knowledge related to blood donation [10, 14, $16,21,25]$. On the other hand, medical students or healthcare workers were indicated to possess appropriate knowledge related to blood donation [13, 17, 18, 19]. To trigger an important amount of potential from university students to donate blood voluntarily; institutions related to blood donation should locate their stands at university campuses at least once a year and they should determine the blood groups of university students who do not know their blood group without any paying. Thus, the university students might be triggered to become a voluntary and regular donor with an activity which explains the characteristics and importance of blood and blood products.

In the present study, more than half of the students who stated that they had never donated blood could not assert any valid reason for this situation. Several researches indicated insufficient number of donors in the literature also $[15,16,23]$. It was determined that those students expressed the reasons such as "I am afraid.", "Hemophobia", "Red Crescent Blood Collection Vehicle did not coincide." and "I do not believe the system." for not being donated blood before. Fear was encountered as a reason of not donating blood in the literature $[20,22,25$, 26]. Additionally, "difficulty in accessing blood donation center" as indicated by Alfouzan [15] was found out as another reason of not donating blood shows similarity to "not coinciding the blood collection vehicle" in this study. Furthermore, in the present study, it was seen that "not becoming sure whether donated blood reached to the people who needed it" was the main reason under the mistrust of university students for not donating blood. When the literature was examined, a similar reason was encountered in Lownik et al.'s [25] study indicating the population's concerns about selling blood. Hence, if adequate conditions are presented for that student group making up about $30 \%$ of the study sample, it is believed that at least several of them will turn into potential voluntary blood donors. This point was also addressed by Shaz et al.'s [37] study which showed convenience to be one of motivators for both donor and non-donor university students at this respect.

Another reason of the fact that university students had negative opinions towards blood donation was their misconceptions. This finding can be supported by the results of a body of research in the literature which asserted misconceptions in various populations $[14,16$, 22]. In his study related to circulatory system in biology education, Özgür [40] identified that students thought clean blood circled in the left side of the body whereas dirty blood circled in the right side of the body. In the present study, several similar results were also obtained. Also, the students in the present study thought that they would suffer from anemia, experience weight loss, faint and get an infectious disease if they donated blood. Concerns about infectious diseases such as HIV were found out as a fundamental barrier to blood donation in the literature also $[16,22,26]$. However, this concern was determined in a lower proportion in the present study. In sum, such a result indicates that people have insufficient knowledge at this aspect.

Becoming aware of the reasons which avoid university students from donating blood will have a key significance on planning of the activities and education programs to trigger them to become a voluntary blood donor. Other researchers also highlight the importance of education at this respect [14].

Secondly, when the results are considered from the positive side, we hold the view that an important amount of contribution can be made to the future awareness studies to be planned in case we know the kind of feelings, opinions and behaviors of university students who have donated blood before. The significance of this view is supported by the findings of Shaz et al.'s study [37]. In their study, the researchers revealed that donors were more likely found to disagree with statements regarding blood donation as being too painful, resulting in feeling faint, dizzy, or nauseated than non-donors. So, the opinions of donors carry much importance.

Within our study sample, the main reason of the students who had donated blood before emerged as the fact that "being sensible". Sensibility is known as precision, the ability to comprehend feelings and the feature to react against a little action. At this respect, sensibility is a characteristic which should be given importance as a society. A sensible citizen is known as an active citizen who reacts to the things happening around his environment. Perhaps it can be accepted as a valid opportunity that the university students can react fast and on time to social cases and needs due to their nature. Helping family and friend $[16,25]$; responsibility to help or rescue another human being in distress or need [26] were other motivating factors to blood donation encountered in the literature which can be accepted to display similarity to the finding "being sensible" in terms of the present study. Accordingly, social motivations of people were found to increase with the increase in number of donations [34].

Despite the fact that several students mentioned "not coinciding Red Crescent Blood Collection Vehicle" for not donating blood, it emerged as an important result that another group of university students asserted "Red Crescent Blood Collection Vehicle" for donating blood. 
As mentioned earlier, it is thought that "Red Crescent Blood Collection Vehicle" triggers blood donation as only itself. This result showed similarity to the finding reported by Alfouzan [15] indicating mobile blood donation caravans in public areas as a serious motivating factor for blood donation.

It was seen that the opinion "Donating blood gives health." was introduced by several university students as a reason of blood donation. We are at the point that serious accomplishments can be obtained from the campaigns related to blood donation if it is highlighted that blood donation will make positive effects on donors' health.

A small amount of university students (about $4.00 \%$ ) pointed out that they donated blood due to their empathy. Since empathy is the comprehension of the situation that another person in, another's feelings or motivation in the behavior and internalization of them; empathizing opportunity might be supplied to the university students and society by addressing the stories and experiences of the people who need blood and blood products on social media platforms as well as written and visual media. The results of the previous research assert altruism at this respect $[16,22]$. Accordingly, TVs are reported to play a significant role to promote blood donation in the society [16]. Also, the positive effects of interventions such as brochures and videos were shown to increase the motivations of college level donors [30].

In the literature it was seen that motivating factors such as token gifts [15, 28], one day off [15] and money [15] contribute people to donate blood. It was remarkable that such behaviors were not observed in Turkish sample. This result might stem from the differences in cultural structure and approaches of people in Turkish population.

\subsection{Suggestions}

The followings can be suggested in order to raise the number of donors from university students in the light of the results of the conducted study:

- Stands should be constructed at the university campuses for blood group determination.

- University students should be accepted as the most efficient group in terms of voluntariness on blood donation by the institutions related to blood donation and awareness studies should be planned according to this view.

- It should be focused that blood donation is not a painful process.

- $\quad$ Red Crescent Blood Collection Vehicles should visit university campuses more frequently and if possible, a stationary blood donation center should be located.

- The fate of each donated blood should be informed to its donor via message or e-mail.

- Misconceptions of the university students related to blood donation should be determined and those misconceptions should be eliminated by developing appropriate didactic instruments.

- It should be noticed that university students constitute a society who are very sensible towards blood donation.

- The slogan "Blood donation gives health both to its donor and receiver." can raise the success of campaigns at this respect.

- Social media platforms, written and visual media should be utilized actively during awareness studies.

\section{REFERENCES}

[1] Online Available: Hematoloji Uzmanlık Derneği,Online available from http://www.hematoloji.org.tr/content.php?gid=20

[2] Purves, W. K., Sadava, D., Orians, G. H., Heller, H. C. Life: the science of biology, Sunderland, MA: Sinauer Associates, (2004).

[3] Kaya, E., Sezek, F., Doğan, S. Üniversite öğrencilerinin kan bağışına karşı tutumları ve kan bağışında alan bilgilerinin etkisinin incelenmesi [The attitudes of university students towards blood donation and investigation of their area knowledge], Cankaya University Journal of Arts and Sciences, Vol.1, No.7, 97-114, 2007.

[4] Hablemitoğlu, Ş., Özkan, Y., Yıldırım, F. Bir fedakâkarlık örneği olarak "kan bağışı" ["Blood donation" as an example of sacrifice], Aile ve Toplum, Vol.5, No.20, 67-77, 2010.

[5] Çelik, C., Güven, G. Kan bağışı tutum ölçeğinin geliştirilmesi: geçerlilik ve güvenilirlik çalışması [The development of blood donation attitude scale: reliability and validity study],Erzincan Üniversitesi Eğitim Fakültesi Dergisi, Vol.17, No.2, 504-521, 2015.doi: 10.17556/jef. 11163

[6] Al-Drees, A. M. Attitude, belief and knowledge about blood donation and transfusion in Saudi population, Pakistan J Med Sci, Vol.24, No.1, 74-79, 2008.

[7] Kınalı Bereketli, S. Kan bağışı yapan üniversite ögrencilerinin bağış nedenleri ve cinsel yolla bulaşan hastalıklara ilişkin bilgi ve risklerinin belirlenmesi [The reasons of blood donation by university students and their knowledge about venereal diseases and the risks of their transmission], Unpublished Master's Thesis. Marmara University, İstanbul, 2009.

[8] Online Available: Türk Kızılayı, Online available from http://www.kanver.org/sayfa/hakkimizda/tarihcemiz/33)

[9] Kocazeybek, B. Kan ve kan ürünleriyle bulaşan infeksiyonlar: rutin tarama testleri ve moleküler tanıma yöntemleri [Infections transmitted by blood and blood products: routine screening tests and molecular diagnostic methods], Cerrahpaşa J Med, Vol.34, No.3, 158-163, 2003.

[10] Yıldız, Ç., Emekdaş, G., Kanık, A., Tiftik, N., Solaz, N., Aslan, G., Tezcan, S., Serin, M. S., Erden, S., Helvacı, İ., Otağ, F. Neden kan bağışlamıyoruz. Mersin ili'nde 
yaşayanlarda kan bağıșına genel bakıș: Anket çalışması [Why don't we donate blood. A general look at the people living in Mersin province: A questionnaire study], İnfeksiyon Dergisi, Vol.20, No.1, 41-55, 2006.

[11] Online Available: World Health Organization [WHO]. Global status report on blood safety and availability 2016, online available from http://apps.who.int/iris

[12] Online Available: Türk Kızılayı, Online available from https://www.kizilay.org.tr/Haber/HaberDetay/3290

[13] Ahmed, Z., Zafar, M., Khan, A.A., Anjum, M.U., Siddique, M.A. Knowledge, attitude and practices about blood donation among undergraduate medical students in Karachi, Journal of Infectious Diseases \& Therapy, Vol.2, No.2, 1-4, 2014. doi:10.4172/2332-0877.1000134

[14] Alam, M., El Din Masalmeh, B. Knowledge, attitudes and practices regarding blood donation among the Saudi population, Saudi Med J, Vol.25, No.3, 318-321, 2004.

[15] Alfouzan, N. Knowledge, attitudes, and motivations towards blood donation among King Abdulaziz medical city population, International Journal of Family Medicine, Vol. 2014, 1-8, 2014.

doi:http://dx.doi.org/10.1155/2014/539670

[16] Baig, M., Habib H., Haji A. H., Alsharief, F. T., Noor, A. M., Makki, R.G. Knowledge, misconceptions and motivations towards blood donation among university students in Saudi Arabia, Pak J Med Sci, Vol.29, No.6, 1295-1299, 2013. doi:

http://dx.doi.org/10.12669/pjms.296.4137

[17] Benedict, N., Usimenahon, A., Alexander, N. I., Isi, A. Knowledge, attitude and practice of voluntary blood donation among physicians in a tertiary health facility of a developing country, International Journal of Blood Transfusion and Immunohematology, Vol.2, 4-10, 2012. doi:10.5348/ijbti20127OA2

[18] Nwogoh, B., Aigberadion, U., Nwannadi, A. I. Knowledge, attitude, and practice of voluntary blood donation among healthcare workers at the university of Benin teaching hospital, Benin city, Nigeria, Journal of Blood Transfusion, Vol.2013, 1-6, 2013. doi: http://dx.doi.org/10.1155/2013/797830

[19] Gazibara, T., Kovacevic, N., Maric, G., Kurtagic, I., Nurkovic, S., Kisic-Tepavcevic, D., Pekmezovic, T. Factors associated with positive attitude towards blood donation among medical students, Transfusion and Apheresis Science, Vol.53, $381 \quad-\quad 385, \quad 2015$. doi:http://dx.doi.org/10.1016/j.transci.2015.07.007

[20] Uma, S., Arun, R., Arumugam, P. The knowledge, attitude and practice towards blood donation among voluntary blood donors in chennai, india, Journal of Clinical and Diagnostic Research, Vol.7, No.6, 1043-1046, 2013. doi: 10.7860/JCDR/2013/4851.3033

[21] Dubey, A., Sonker, A., Chaurasia, R., Chaudhary, R. Knowledge, attitude and beliefs of people in North India regarding blood donation, Blood Transfus, Vol.12, No.1, 21-27, 2014. doi: 10.2450/2012.0058-12

[22] Zaller, N., Nelson, K.E., Ness, P., Wen, G., Bai, X., Shan, $\mathrm{H}$. Knowledge, attitude and practice survey regarding blood donation in a Northwestern Chinese city, Transfusion
Medicine, Vol.15, 277-286, 2005. doi: 10.1111/j.1365-3148.2005.00589.x

[23] Mousavi, F., Tavabi, A.A., Golestan, B., Ammar-Saeedi, E., Kashani, H., Tabatabaei, R., Iran-Pour, E. Knowledge, attitude and practice towards blood donation in Iranian population, Transfusion Medicine, Vol.21, 308-317, 2011. doi: $10.1111 / \mathrm{j} .1365-3148.2011 .01080 . \mathrm{x}$

[24] Melku, M., Terefe, B., Asrie, F., Enawgaw, B., Melak, T., Tsegay,Y.G., Areba,M., Shiferaw, E. Knowledge, attitude, and practice of adult population towards blood donation in Gondar town, northwest Ethiopia: a community based cross-sectional study, Journal of Blood Transfusion, Vol. 2016, 1-10, 2016. doi:

http://dx.doi.org/10.1155/2016/7949862

[25] Lownik, E., Riley, E., Konstenius, T., Riley, W., McCullough, J. Knowledge, attitudes and practices surveys of blood donation in developing countries, International Journal of Transfusion Medicine, Vol.103, 64-74, 2012. doi: $10.1111 / \mathrm{j} .1423-0410.2012 .01600 . \mathrm{x}$

[26] Koster, J., O. W. Hassall, O.W. Attitudes towards blood donation and transfusion in Bamenda, Republic of Cameroon, Transfusion Medicine, Vol.21, 301-307, 2011. doi: $10.1111 / \mathrm{j} .1365-3148.2011 .01079 . \mathrm{x}$

[27] Kalargirou, A.A., Beloukas, A. I., Kosma, A.G., Nanou, C. I., Saridi, M. I., Kriebardis, A. G. Attitudes and behaviours of Greeks concerning blood donation: recruitment and retention campaigns should be focused on need rather than altruism, Blood Transfus, Vol.12, 320-329, 2014. doi: $10.2450 / 2014.0203-13$

[28] Glynn, S.A., Williams, A.E., Nass, C.C., Bethel, J., Kessler, D., Scott, E.P., Fridey, J., Kleinman, S.H., Schreiber, G.B. Attitudes toward blood donation intensives in the United States: implications for donor recruitment, Transfusion, Vol.43, 7-16, 2003.

[29] Cevizci, S., Erginöz, E., Yüceokur, A. Gönüllü kan bağışçılığ1 ve kan verme davranışını etkileyen faktörler [Voluntary blood donation and the factors affecting that behavour], Türkiye Klinikleri J Cardiovasc Sci., Vol.22, No.1, 85-92, 2010.

[30] France, C.R., France, J.L., Wissel, M.E., Kowalsky, J.M., Bolinger, E.M., Huckins, J.L. Enhancing blood donation intentions using multimedia donor education materials, Transfusion, Vol. 51, 1796-1801, 2011. doi: $10.1111 /$ j.1537-2995.2010.03033.x

[31] Merav, B. N., Lena, G. Investigating the factors affecting blood donation among Israelis, International Emergency Nursing, Vol. 19, 37- 43, 2011. doi:10.1016/j.ienj.2010.01.003

[32] Veldhuizen, I., Ferguson, E., de Kort, W., Donders, R., Atsma, F. Exploring the dynamics of the theory of planned behavior in the context of blood donation: does donation experience make a difference?, Transfusion, Vol.51, 2425-2437, 2011. doi: 10.1111/j.1537-2995.2011.03165.x

[33] van Dongen, A., Abraham, C., Ruiter, R. A. C., Veldhuizen, I. J. T. Does questionnaire distribution promote blood donation? An Investigation of question-behavior effects, Ann. Behav. Med., Vol.45, 163-172, 2013. Doi: $10.1007 / \mathrm{s} 12160-012-9449-3$ 
[34] Guiddi, P., Alfieri, S., Marta, E., Saturni, V. New donors, loyal donors and regular donors: which motivation sustain blood donation? Transfusion and apheresis science, Vol.52, 339-344, 2015.

[35] France, C.R., France, J.L., Carlson, B.W., Kessler, D.A., Rebosa, M., Shaz, B.H., Madden, K., Carey, P.M., Fox, K.R., Livitz, I.E., Ankawi, B., Slepian, P. M. A brief motivational interview with action and coping planning components enhances motivational autonomy among volunteer blood donors, Transfusion, Vol.56, 1636-1644, 2016. doi:10.1111/trf. 13485

[36] Alfieri, S., Guiddi, P., Marta, E., Saturni, V. Economic crisis and blood donation: How are donors' motivations changing? Transfusion and Apheresis Science, Vol. 54, $396-400,2016$

doi:http://dx.doi.org/10.1016/j.transci.2016.03.001

[37] Shaz, B.H., Demmons, D.G., Crittenden, C.P., Carnevale,
C.V., Lee, M., Burnett, M., Easley, K., Hillyer, C.D. Motivators and barriers to blood donation in African American college students, Transfusion and Apheresis Science, Vol.41, 191-197, 2009.

doi:10.1016/j.transci.2009.09.005

[38] Pentecost, R., Arli, D., Thiele, S. "It's my choice! Investigating barriers to pro-social blood donating behaviour", Marketing Intelligence \& Planning, Vol.35, No.2, 243-258, 2017. doi: https:// doi.org/10.1108/MIP-03-2016-0055

[39] Yıldırım, A., Şimşek, H.Sosyal bilimlerde nitel araştırma yöntemleri [Qualitative research methods in social sciences], Ankara: Seçkin Yayıncılık, 2008.

[40] Özgür, S. The persistence of misconceptions about the human blood circulatory system among students in different grade levels, International Journal of Environmental \& Science Education, Vol.8, No.2, 255-268, 2013. 